\title{
MENGUKUR TINGKAT KEPUASAN NASABAH DENGAN ANALISIS TINGKAT KEPENTINGAN DAN KEPUASAN PELANGGAN
}

\author{
Mahrawati \\ Email : mahrawati@gmail.com \\ STIE Palangka Raya
}

\section{ABSTRACT}

There are quite similar reasons for debtors in selecting bank to the reasons in keeping funds. It is not merely concerning interest rate and facilities, service is also an important factor. This factor is greatly important regarding business activity between one bank and others can be said to be the same. The different thing is a matter of services.

This research is located in Mandiri Bank Palangka Raya Branch. This research aims to (1) determine and analyze the level of conformity of interest level of service elements according to customers on the performance that has been conducted by Mandiri Bank Palangka Raya Branch (2) to determine customers' satisfaction on the services that have been given so that it can assist the Mandiri Bank performance to achieve better quality improvement through determination of main priority.

The samples are 100 customers of Mandiri Bank Palangka Raya Branch as the respondents using accidental sampling technique, the analysis used is customers' Importance-Performance analysis. This analysis uses Cartesians Diagram divided into four quadrants. In this research, there are some main considerations by Mandiri Bank Palangka Raya Branch namely (a) Teller attention to the customers, employee willingness to service the customers (b) Waiting time in the queue (c) existence of Mandiri ATM machine (d) Interest rate level given by the bank.

Keywords: Customer Satisfaction, Importance level, Customer Satisfaction 


\section{PENDAHULUAN}

Kualitas pelayanan sebuah bank adalah indicator subjektif yang sulit diukur. Karena standar yang berbeda, pelayanan bank-bank asing tertentu berbeda jauh dengan pelayanan di bank-bank pemerintah. Umumnya, masalah pelayanan sebuah bank terkait dengan kualitas sumber daya manusia (SDM) pada bank tersebut. Lebih lanjut, kualitas SDM ini terkait dengan profesionalitas. Kembali, professionalitas merupakan factor subjektif yang sulit diukur dan dimiliki banyak standar. Oleh karena itu, untuk menilai dan memperbandingkan bank-bank yang ada di sekitar kita, kita bisa menggunakan indikator-indikator perbankan yang memiliki satu standar.

The Bank for International Settlement (BIS) menganjurkan perbakan internasional memiliki CAR minimal 8\%. CAR dapat diibaratkan sebagai daya tahan tubuh. Makin besar CAR suatu bank, berarti kesiapan mengadapi kredit macet besar pula. Jika CAR memiliki nilai negatif sebagaimana CAR bankbank yang dilikuidasi beberapa waktu lalu berarti sekalipun modal bank dipakai untuk membayar kredit, kredit bank tersebut tetap belum terlunasi. Namun secara ekstem, bank yang sedikit saja mengucurkan kredit kepada nasabah (sehigga hamper tidak memiliki asset berisiko) memiliki persentase CAR yang amat besar. Indikator berikutnya yaitu kredit bermasalah (Non Performing Loans/NPL) adalah kredit yang tidak lancar.

Besarnya NPL ditunjukan dengan persentase perbandingan kredit bermasalah dengan kredit yang dikucurkan bank. Kredit yang diberikan kepada bank kepada nasabah dapat dibedakan menjadi lima kelompok yakni lancer dalam perhatikan khusus, kurang lancar, diragukan, dan macet. Empat kelompok koletibilitas yang terakhir merupakan kredit bermasalah atau NPL. Namun demikian, sebuah bank yang memiliki NPL sangat kecil tidak serta merta berarti hamper seluruh 
kredit bank tersebut adalah kredit lancar, yang menunjukan betapa sehatnya bank tersebut dan indikator LDR (Loan to Deposit Ratio) yang merupakan perbandingan antara kredit yang disalurkan dengan dana masyarakat yang dikumpulkan bank (dana pihak ketiga, baik berupa tabungan maupun deposito).

Kenaikan LDR berarti meningkatnya ekspansi kredit bank tidak diimbangi dengan pengumpulan dana pihak ketiga, atau dari sisi lain berarti dana pihak ketiga yang dikumpulkan bank menurun. Sementara, bank yang memiliki LDR sangat kecil berarti bank tersebut tidak menjalankan fungsi intermediasi dengan baik.

Bank-bank seperti ini umumnya hanya menampung dana pihak ketiga, kemudian melakukan plancing di pasar uang untuk mencari profit tanpa menyalurkan kredit kepada masyarakat. Selain indikatorindikator tersebut yang penting di perhatikan mengenai kualitas pelayanan yang diberikan apakah sudah dilakukan sesuai dengan harapan pelanggannya dalam hal ini adalah nasabah. Yang menjadi objek dalam laporan penelitian ini dilakukan terhadap nasabah Bank Mandiri Cabang Palangka Raya.

Tujuan yang hendak dicapai dalam penelitian ini adalah (1) Untuk mengetahui dan menganalisa sampai sejauh mana kesesuaian antara tingkat kepentingan unsur-unsur pelayanan menurut pelanggan/nasabah dengan kinerja yang telah dilakukan oleh Bank Mandiri (2) Untuk mengetahui kepuasan dari nasabah terhadap pelayanan yang telah diberikan sehingga membantu kinerja Bank Mandiri agar tercapai peningkatan kualitas yang baik melalui penentuan proritas yang utama.

\section{TINJAUAN PUSTAKA}

\section{Definisi Jasa}

Perkembangan manajemen pemasaran berawal dari tukar menukar barang secara sederhana tanpa menggunakan alat tukar berupa uang ataupun logam mulia. Dengan berkembangnya ilmu pengetahuan, maka dibutuhkannya 
suatu alat tukar yang berlaku umum dan untuk itulah diciptakan uang. Disamping itu, manusia memerlukan jasa yang mengurus hal-hal tertentu, sehingga jasa menjadi bagian utama dalam pemasaran.

Jasa/pelayanan merupakan suatu kinerja penampilan, tidak berwujud dan tetap hilang, lebih dapat dirasakan daripada memiliki, serta pelanggan lebih dapat berpartisipasi aktif dalam proses mengkonsumsi jasa tersebut. Dalam strategi pemasaran, defenisi jasa harus diamati dengan baik, karena pengertian sangat berbeda dengan produk berupa barang. Kondisi dengan cepat lambatnya pertumbuhan jasa akan sangat bergantung pada penilaian pelanggan terhadap kinerja (penampilan) yang ditawarkan oleh pihak produsen.

\section{Karakteristik Jasa}

\section{Pengertian Kepuasan}

Kepuasan adalah tingkat perasaan seseorang setelah membandingkan kinerja atau hasil yang dirasakan dengan harapannya (J. Supranto, 1997). Jadi tingkat
Menurut Philip Kotler (2011) Karakteristik jasa adalah : (a) Intangible (tidak berwujud) yaitu suatu jasa mempunyai sifat tidak berwujud, tidak dapat dirasakan dan dinikmati sebelum dibeli oleh konsumen. (b) Inseparibility (tidak dapat dipisahkan) yaitu pada umumnya jasa yang diproduksi dan dirasakan pada waktu bersamaan dan apabila dikehendaki oleh seseorang untuk diserahkan kepada pihak lainnya, maka dia akan tetap merupakan bagian dari jasa tersebut. (c) Variabelity (bervariasi) yaitu jasa senantiasa mengalami perubahan, tergantung siapa penyedia jasa, penerima jasa dan kondisi dimana jasa itu diberikan (d) Pershability (tidak tahan lama) yaitu daya tahan jasa tergantung suatu situasi yang diciptakan oleh berbagai faktor.

kepuasan merupakan fungsi dari perbedaan antara kinerja yang dirasakan dengan harapan. Apabila kinerja dibawah harapan, maka pelanggan akan kecewa. Bila kinerja 
sesuai dengan harapan, maka atau jasa yang dibeli dengan pelanggan akan puas. Sedangkan kebutuhan, secara logika mereka bila kinerja melebihi harapan, merasa puas, karena dalam pelanggan akan sangat puas.

menentukan nilai produk, pelanggan

Harapan pelanggan dapat dibentuk oleh pelanggan masa lampau, komentar dari kerabatnya serta janji dan informasi pemasar dan saingannya. Pelanggan yang puas akan setia lebih lama, kurang sensitifterhadap harga dan memberi komentar yang baik tentang perusahaan.Untuk menciptakan kepuasan pelanggan/nasabah, perusahan harus menciptakan dan mengelola suatu system untuk memperoleh pelangan yang lebih banyak dan kemampuan untuk mempertahankan pelanggannya.

\section{Nilai Produk Bagi Pelanggan}

\section{a. Nilai Total Pelanggan}

Dengandijalankannya masscustomization, yang mana setiap pelanggan bisa meyesuaikan produk terlibat langsung ikut menentukan. Demikain juga untuk jasa, personil dan citra, pelangan terlibat secara aktif, sehingga merekan mendapatkan kepuasan. Akibat lebih lanjut, nilai total pelanggan meningkat jika dibanding tanpa adanya masss customization.

\section{b. Biaya Total Pelanggan}

Dengan adanya mass customization, biaya moneter, harga misalnya menjadi lebih murah. Biaya dari unsur waktu, misalnya waktu untuk mencari dan mendisain produk atau jasa yang benar-benar sesuai sebelum adanya mass customization akan lebih panjang, berarti akan lebih mahal, namun setelah perusahaan menjalankan mass customization, biaya menjadi lebih rendah

\section{c. Nilai Yang Diserahkan Kepada Pelanggan}

Apabila nilai total pelanggan meningkat dengan adanya mass customization, sementara biaya total pelanggan justru menurun, berarti nilai yang diserahkan kepada pelanggan menjadi lebih tinggi dibanding sebelumnya. 


\section{Harapan Pelanggan Terhadap}

\section{Produk}

Denganditerapkannyamasscust omization, harapan pelanggan terhadap produk relativebisa tepat.Pengalaman membeli yang menyenangkan, informasi dan janji yang dipenuhi sesuai kenyataan, maka harapan pelanggan menjadi lebih tinggi.

Ketika nilai produk bagi pelanggan meningkat karena pelaksanaan masscustomization, dan harapan pelanggan terhadap produk tepat, maka tingkat kepuasan pelanggan menjadi lebih tinggi dibanding sebelumnya.

\section{Pengertiandan Fungsi Bank}

Menurut GM VerrynStuart dalam Simorangir (1989), definisi bank adalah badan yang bertujuan untuk memuaskan kebutuhan kredit, baik dengan alat-alat pembayaran sendiri atau uang yang diperolehnya dari orang lain maupun dengan jalan mengedarkan alat-alat pertukaran

\section{KonsepPemasaranPerbankan}

baru berupa uang giral.Menurut Drs. H. Malayu SP Hasibuan (2003), bank adalah lembaga keuangan, pencipta uang, mengumpul dana, memberi kredit, mempermudah pembayaran atau tagihan, stabilisator moneter dan dinamisator perekonomian.

Fungsi bank lainnya adalah fungsi pengguna atau penyalur kredit yang dapat diklarifikasikanmenjadi kelompok besar, yaitu : peminjaman (kredit), investasi. aktifa lancar, dan fasilitas bank. Fungsi utama bank menurut Reed dan Gill (2009), yaitu (a) Kemampuan untuk membuat dan memusnahkan uang (b) Mekanisme pembayaran dan transfer dana (c) Pemusatan dan pengumpulan dana (d) Penyaluran kredit (e) Fasilitas pembiayaan dan perdaganagan luar negeri (f) Jasa-jasa perwalian atau trust (g) Penyimpanan dana-dana berharga (h) Jasa-jasa penawaran dan penjualan dan pembelian surat berharga. 
Sebagaimana dalam penjualan jasa, aktifitas pemasaran dalam industri perbankan memfokuskan pada konsumen atau nasabah itu sendiri. Pemasar menjadi orang yang melayani dan berusaha mengetahui jasa yang sesuai dengan keinginan konsumen.

Dalam aktivitas pemasaran jasa bank, terdapat dua kegiatan yang dilakuakan secara bersama-sama (dual marketing task), yaitu kegiatan pemasaran untuk menghimpun dana (dalam bentuk simpanan) dan kegiatan pemasaran untuk memasarkan dana (dalam bentuk pinjaman atau kredit), serta jasa-jasa perbankan lainya.

$$
\text { PhilipKotler(2007), }
$$

mengungkapkan bahwa dalam industri perbankan, pengertian pemasaran bank adalah (a) Pemasaran adalah iklan, promosi penjualan, dan publikasi, dengan tujuan untuk menarik nasabah baru dan memperkenalkan produk jasa bank (b) Pemasaran adalah menciptakan suasana yang menyenangkan dan bersahabat.
Bankir serta seluruh pihak di bank dituntut untuk bersikap ramah terutama pada bagian yang berhadapan langsung dengan nasabah (c) Pemasaran adalah segmentasi dan inovasi, dimana dalam bersaing baik dituntut untuk dapat mengantisipasi segala kebutuhan nasabahnya dengan melakukan sigmintasi pasar serta memperkenalkan produk-produk baru (d) Pemasaran adalah pembentukan posisi (postioning), dimana bank dituntut untuk memiliki ketidaksamaan dengan bank-bank lain. Postioning pada dasarnya membantu mengetahui perbedaan suatu bank dari bank-bank pesaing (e)Pemasaran adalah analisis, perencanaan, dan pengawasan pemasaran, dimana bank dituntut untuk melakukan analisis, perencanaan, dan pengawasan pemasaran yang efektif sehingga mampu sasaran yang telah ditetepkan serta mampu bertahan dalam pesaingan yang semakin ketat.

Menurut Berry(1990), bahwa jasa perbankan bersifat ingtangible 
yang berupa pelayanan (servise) sehingga diperlukan strategi pemasaran yang menggunakan konsep 4 P (Product, Price, Place, dan Promotion), 2 C (Customer sensitivity and Customer confinience), dan $\mathrm{S}$ (Service). Konsep $4 \mathrm{P}+2 \mathrm{C}+\mathrm{S}$ adalah sebagai (a)Product, yaitu mutu, keandalan, dan atribut-atribyt produk (b) Price, yaitu harga yang ditetapkan, syarat-syarat pembayaran, dan kemudahan-kemudahan lainnya (c) Place, yaitu aksesabilitas produsen, fasilitas yang dimiliki produsen, syarat pembayaran, dan kesediaan bagi nasabah (d) Promotion, yaitu periklanan, pubilitas, layanan prajual, dan potongan harga (e) Kepekaan pelanggan (Customer sensitivity), yaitu sikap karyawan, perlakuan terhadap nasabah, dan tanggapan terhadap nasabah (f) Kemudahan dan keyamanan nasabah (Customer confinience), yaitu kesediaan nasabah, kenyamanan nasabah, dan penjualan (g) Layanan atau jasa (Service), yaitu pelayanan pra-jual, pelayanan purnajual, dan kenyamanan nasabah.

\section{METODE PENELITIAN}

\section{Jenis Data}

Jenis data yang digunakan dalam penelitian ini adalah data kualitatif dan data kuantitatif. Data kuantitatif dibagi menjadi dua, yaitu: datadiskrit/nominal dan data kontinyu. Data nominal adalah data yang hanya dapat digolonggolongkan secara terpisah, secara diskrit atau kategori.

Skala pengukuran merupakan kesepakatan yang digunakan sebagai acuan untuk menentukan panjang pendeknya interval yang ada dalam alat ukur, sehingga alat ukur tersebut bila digunakan dalam pengukuran akan menghasilkan data kuantitatif. Dengan skala pengukuran ini, maka nilai variabel yang diukur dengan instrumen tertentu dapat dinyatakan dalam bentuk angka, sehingga akan lebih akurat, efisien, dan komunikatif.

\section{Jenis Skala Pengukuran}

a. Skala Likert

Skala ini digunakan untuk mengukur sikap, pendapat, dan persepsi seseorang atau sekelompok orang tentang fenomena sosial. Dengan skala Likert, maka variable 
yang akan diukur dijabarkan menjadi indikator variabel. Kemudian indicator jawaban tersebut dijadikan sebagai titik tolak untuk menyusun butir-butir yang dapat berupa pernyataan dan pertanyaan. Jawaban setiap butir yang menggunakan skala Likert berupa kata-kata.
Dalam hal ini, digunakan skala4 (empat) tingkat (Likert) yang terdiri: sangat penting, penting, kurang penting, dan tidak penting untuk pertanyaan tentang harapan nasabah terhadap suatu aspek. Keempat penilaian tersebut diberikan bobot :

a. Jawaban sangat penting diberi bobot 4 (empat)

b. Jawaban penting diberi bobot 3 (tiga)

c. Jawaban kurang penting diberi bobot 2 (dua)

d. Jawaban tidak penting diberi bobot 1 (satu)

\section{Skala Guttman}

Skala pengukuran dengan tipe ini akan didapatkan jawaban yang tegas yaitu: Ya atau Tidak, Benar atau Salah. Data yang diperoleh dapat berupa data interval atau ratio. Jadi jika pada skala Likert terdapat interval dari kata "sangat setuju " sampai "tidak setuju", maka pada skala Guttman hanya ada dua interval yaitu "setuju" atau "tidak setuju”. Penelitian yang menggunakan skala Guttman dilakukan bila ingin mendapatkan jawaban yang tegas terhadap suatu permasalahan yang ditanyakan.

\section{Validitas dan Reliabilitas}

Ada syarat penting yang berlaku pada sebuah angket kuisioner, yaitu keharusan sebuah angket kuisioner untuk Valid dan Reliabel. Suatu angket dikatakan valid (sah) jika pertanyaan pada suatu angket mampu untuk mengungkapkan sesuatu yang akan diukur oleh angket tersebut. Suatu angket dinyatakan valid jika angket tersebut mampu mengukur apa saja yang hendak diukurnya, mampu mengungkapkan apa yang ingin diungkapkan, mampu menembak dengan jitu sasaran yang hendak ditembak. Sedangkan angket dikatakan reliabel (andal) jika 
jawaban seseorang terhadap selanjutnya adalah menguju apakah pertanyaan adalah konsisten atau faktor- faktor sudah valid untuk stabil dari waktu ke waktu.

mengukur konstrak yang ada.

Pengujian validitas dan

\section{HASIL PENELITIAN}

reliabilitas adalah proses menguji

Analisis dimulai dengan

butir- butir pertanyaan yang ada menguji validitas terlebih dahulu, dalam sebuah kuisioner, butir selanjutnya menguji reliabilitasnya. pertanyaan tersebut sudah valid dan reliabel atau belum. Jika butir-butir sudah valid dan reliabel, berarti butirJadi jika sebuah butir tidak valid, maka otomatis butir tersebut dibuang. Butir-buitr yang sudah butir tersebut sudah bisa untuk valid kemudian secara bersama-sama mengukur faktornya. Langkah diukur reliabilitasnya.

\section{Pengujian Hipotesis}

Tabel 3

Hasil Analisis Kevalidan Dari Faktor-faktorYang Mempengaruhi Kepuasan Nasabah Bank Mandiri

\begin{tabular}{|c|l|c|c|}
\hline No & $\begin{array}{l}\text { Faktor-faktor yang Mempengaruhi Kepuasan } \\
\text { Nasabah Bank Mandiri }\end{array}$ & $\begin{array}{c}\text { Koefisien } \\
\text { Korelasi }\end{array}$ & Keterangan \\
\hline A & ASPEK KETANGGAPAN PELAYANAN & & \\
\hline 1 & Pelayanan transaksi kepada nasabah & 0,477 & Valid \\
\hline 2 & Kecepatan teller melakukan transaksi & 0,533 & Valid \\
\hline 3 & Tanggapan teller kepada nasabah & 0,579 & Valid \\
\hline 4 & Perhatian Teller kepada nasabah & 0,592 & Valid \\
\hline 5 & Kesungguhan semua karyawan melayani nasabah & 0,259 & Valid \\
\hline B & ASPEK KECEPATAN TRANSAKSI & & \\
\hline 6 & Proses transaksi kepada nasabah & 0,484 & Valid \\
\hline 7 & Waktu menunggu dalamantrian & 0,433 & Valid \\
\hline 8 & Waktu yang diperlukan seluruh transaksi & 0,630 & Valid \\
\hline 9 & Waktu menunggu begitu sampai di loket & 0,604 & Valid \\
\hline 10 & Kesigapan teller melayani nasabah & 0,470 & Valid \\
\hline C & ASPEK KEBERADAAN PELAYANAN & & \\
\hline 11 & Sambutan segenap karyawan kepada nasabah & 0,365 & Valid \\
\hline 12 & Teller memberikan senyumyang ramah & 0,197 & Tidak Valid \\
\hline 13 & Waktu pertemuan Saya dengan pegawai & 0,516 & Valid \\
\hline D & ASPEK PROFESIONALISME PELAYANAN & & \\
\hline 14 & Kesungguhan teller melayani nasabah & 0,567 & Valid \\
\hline 15 & Teller mendengarkan permintaan nasabah & 0,467 & Valid \\
\hline 16 & Waktu yang diperlukan Teller untuk bertransaksi & 0,394 & Valid \\
\hline
\end{tabular}




\begin{tabular}{|c|l|c|c|}
\hline 17 & $\begin{array}{l}\text { Teller tahu bagaimana menangani suatu transaksi } \\
\text { spesial yang nasabah minta }\end{array}$ & 0,560 & Valid \\
\hline 18 & $\begin{array}{l}\text { Teller tidak minta bantuan dari teller lain untuk } \\
\text { suatu transaksi yang nasabah minta. }\end{array}$ & 0,495 & Valid \\
\hline 19 & Kemampuan teller melakukan transaksi & 0,436 & Valid \\
\hline E & $\begin{array}{l}\text { ASPEK FASILITAS YANG DIBERIKAN } \\
\text { OLEH BANK }\end{array}$ & 0,230 & Valid \\
\hline 20 & Waktu menunggu di antrian di ATM & 0,211 & Valid \\
\hline 21 & Keberadaan mesin ATM & 0,108 & Tidak Valid \\
\hline 22 & Adanya SMS banking BRI & 0,364 & Valid \\
\hline 23 & Programundian berhadiah yang diadakan oleh bank & $\begin{array}{c}\text { Koefisien } \\
\text { Korelasi }\end{array}$ & Keterangan \\
\hline No & Faktor-faktor yang Mempengaruhi & 0,426 & Valid \\
\hline 24 & Tingkat suku bunga yang diberikan bank selama ini \\
\hline
\end{tabular}

Posisi penempatan data yang telah dianalisa tersebut, menjadi empat bagian yaitu (a). Menunjukkan unsur jasa pokok yang telah berhasil dilaksanakan pihak bank, untuk itu wajib dipertahankan. Dianggap sangat penting dan memuaskan (b). Menunjukkan factor yang mempengaruhi pelanggan kurang penting, akan tetapi pelaksanaannya berlebihan. Dianggap kurang penting tetapi sangat memuaskan (c). Menunjukkan beberapa faktor yang

Tabel 4.

Perhitungan Rata-rata Dari Penilaian Pelaksanaan Dan Penilaian Kepentingan Pada Faktor-faktorYang Mempengaruhi Kepuasan Nasabah

\begin{tabular}{|c|c|c|c|c|c|c|}
\hline No & ASPEKKETANGGAPANPELAYANAN & $\begin{array}{l}\text { Penilaian } \\
\text { Kinerja }\end{array}$ & $\begin{array}{l}\text { Penilaian } \\
\text { Harapan }\end{array}$ & $\begin{array}{l}X \\
-\end{array}$ & $\begin{array}{l}\Upsilon \\
-\end{array}$ & $\begin{array}{l}\text { Penilaian } \\
\text { Kesesuaian }\end{array}$ \\
\hline 1 & Pelayanantransaksi kepadanasabah & 321 & 385 & 3,21 & 3,85 & $83,38 \%$ \\
\hline 2 & Kecepatantellermelakukantransaksi & 306 & 371 & 3,06 & 3,71 & $82,48 \%$ \\
\hline 3 & Tanggapantellerkepadanasabah & 299 & 372 & 2,99 & 3,72 & $80,38 \%$ \\
\hline 4 & PerhatianTellerkepadanasabah & 276 & 369 & 2,76 & 3,69 & $74,80 \%$ \\
\hline
\end{tabular}




\begin{tabular}{|c|c|c|c|c|c|c|}
\hline 5 & $\begin{array}{l}\text { Kesungguhansemuakaryawanmelayani } \\
\text { nasabah }\end{array}$ & 259 & 369 & 2,59 & 3,69 & $70,19 \%$ \\
\hline $\mathbf{B}$ & ASPEKKECEPATANTRANSAKSI & & & & & \\
\hline 6 & Prosestransaksi kepadanasabah & 286 & 361 & 2,86 & 3,61 & $79,22 \%$ \\
\hline 7 & Waktumenunggu dalamantrian & 247 & 340 & 2,47 & 3,40 & $72,65 \%$ \\
\hline 8 & Waktuyangdiperlukanseluruhtransaksi & 273 & 334 & 2,73 & 3,34 & $81,74 \%$ \\
\hline 9 & Waktumenunggu begitusampai di loket & 265 & 329 & 2,65 & 3,29 & $80,55 \%$ \\
\hline 10 & Kesigapantellermelayani nasabah & 291 & 351 & 2,91 & 3,51 & $82,91 \%$ \\
\hline $\mathbf{C}$ & ASPEKKEBERADAANPELAYANAN & & & & & \\
\hline 11 & Sambutansegenapkaryawankepadanasabah & 266 & 330 & 2,66 & 3,30 & $80,61 \%$ \\
\hline 13 & WaktupertemuanSaya denganpegawai & 273 & 294 & 2,73 & 2,94 & $92,86 \%$ \\
\hline $\mathbf{D}$ & $\begin{array}{l}\text { ASPEKPROFESIONALISME } \\
\text { PELAYANAN }\end{array}$ & & & & & \\
\hline 14 & Kesungguhantellermelayani nasabah & 328 & 366 & 3,28 & 3,66 & $89,62 \%$ \\
\hline 15 & Tellermendengarkanpermintaannasabah & 320 & 372 & 3,20 & 3,72 & $86,02 \%$ \\
\hline 16 & $\begin{array}{l}\text { Waktuyang diperlukan Teller untuk } \\
\text { bertransaksi }\end{array}$ & 280 & 337 & 2,80 & 3,37 & $83,09 \%$ \\
\hline 17 & $\begin{array}{l}\text { Tellertahubagaimanamenangani suatu } \\
\text { transaksi spesial yangnasabahminta }\end{array}$ & 309 & 361 & 3,09 & 3,61 & $85,60 \%$ \\
\hline 18 & $\begin{array}{l}\text { Tellertidakmintabantuandari tellerlainuntuk } \\
\text { suatutransaksi yangnasabahminta. }\end{array}$ & 303 & 310 & 3,03 & 3,10 & $97,74 \%$ \\
\hline 19 & Kemampuantellermelakukantransaksi & 331 & 359 & 3,31 & 3,59 & $92,20 \%$ \\
\hline $\mathbf{E}$ & $\begin{array}{l}\text { ASPEKFASILITASYANGDIBERIKAN } \\
\text { OLEH BANK }\end{array}$ & & & & & \\
\hline 20 & Waktumenunggu di antrian di ATM & 265 & 320 & 2,65 & 3,20 & $82,81 \%$ \\
\hline 21 & KeberadaanmesinATM & 239 & 371 & 2,39 & 3,71 & $64,42 \%$ \\
\hline 23 & $\begin{array}{l}\text { Programundianberhadiahyangdiadakanoleh } \\
\text { Bank }\end{array}$ & 252 & 323 & 2,52 & 3,23 & $78,02 \%$ \\
\hline 24 & $\begin{array}{l}\text { Tingkat sukubungayang diberikan bank selama } \\
\text { Ini }\end{array}$ & 237 & 342 & 2,37 & 3,42 & $69,30 \%$ \\
\hline & \multicolumn{3}{|c|}{ Rata-rataXdan $Y$} & 2,83 & 3,48 & \\
\hline
\end{tabular}

Setelah diketahui kevalidan dilakukan perbaikan dan butir-bitir pertanyaan, maka peningkatan. Untuk itu dapat dilihat selanjutnya dapat diketahui butir tabel 5 di bawah ini: mana saja yang sebaiknya akan

\section{Tabel 5.}

HasilAnalisis Dari Tingkat Kepentingan

\begin{tabular}{|c|c|c|c|}
\hline Butir Ke & Kinerja & Harapan & Kuadran \\
\hline 1 & 3,21 & 3,85 & I \\
\hline 2 & 3,06 & 3,71 & I \\
\hline 3 & 2,99 & 3,72 & I \\
\hline 4 & 2,76 & 3,69 & IV \\
\hline 5 & 2,59 & 3,69 & IV \\
\hline 6 & 2,86 & 3,61 & I \\
\hline 7 & 2,47 & 3,40 & IV \\
\hline 8 & 2,73 & 3,34 & III \\
\hline 9 & 2,65 & 3,29 & III \\
\hline
\end{tabular}




\begin{tabular}{|c|c|c|c|}
\hline 10 & 2,91 & 3,51 & I \\
\hline 11 & 2,66 & 3,30 & III \\
\hline 13 & 2,73 & 2,94 & III \\
\hline 14 & 3,28 & 3,66 & I \\
\hline 15 & 3,20 & 3,72 & I \\
\hline 16 & 2,80 & 3,37 & III \\
\hline 17 & 3,09 & 3,61 & I \\
\hline 18 & 3,03 & 3,10 & II \\
\hline 19 & 3,31 & 3,59 & I \\
\hline 20 & 2,65 & 3,20 & III \\
\hline 21 & 2,39 & 3,71 & IV \\
\hline 23 & 2,52 & 3,23 & III \\
\hline 24 & 2,37 & 3,42 & IV \\
\hline Rata-rata & $\mathbf{2 , 8 3}$ & $\mathbf{3 , 4 8}$ & \\
\hline
\end{tabular}

Faktor-faktor yangterdapat Teller tahu bagaimana menangani

pada Kuadran I merupakan faktorfaktor yang perlu dipertahankan pelaksanaannya, karena sudah sesuai dengan harapan pelanggan (a).Pelayanan transaksi kepada nasabah dengan tingkat kesesuaian 83,38\%. (b) Kecepatan teller melakukan transaksi dengan tingkat kesesuaian $82,48 \% \quad$ (c)Tanggapan teller kepada nasabah dengan tingkat kesesuaian 80,38\%. (d) Proses transaksi kepada nasabah dengan tingkat kesesuaian $79,22 \%$ (e)Kesigapan teller melayani nasabah dengan tingkat kesesuaian 82,91\%. (f)Kesungguhan teller melayani nasabah dengan tingkat kesesuaian 89,62\%. (g) Teller mendengarkan permintaan nasabah dengan tingkat kesesuaian 86,02\%. (h) suatu transaksi spesial yang nasabah minta dengan tingkat kesesuaian $85,60 \%$. (i) Kemampuan teller melakukan transaksi dengan tingkat kesesuaian 92,20\%.

Kuadran II merupakan faktorfaktor yang pelaksanaannya dilakukan dengan sangat baik oleh pihak bank, namun dinilai kurang penting oleh nasabah, sehingga terkesan berlebihan. Faktor-faktor tersebut antara lain: (a)Teller tidak minta bantuan dari teller lain untuk transaksi yangnasabah minta dengan tingkat kesesuaian 97,74\%.

Kuadran III merupakan faktorfaktor yang dinilai kurang penting oleh nasabah, akan tetapi telah dilakukan dengan cukup oleh pihak bank. Faktor-faktor itu adalah (a) 
Waktu yang diperlukan seluruh transaksi dengan tingkat kesesuaian 81,74\%. (b) Waktu menunggu begitu sampai di loket dengan tingkat kesesuaian $80,55 \%$. (c) Sambutan segenap karyawan kepada nasabah dengan tingkat kesesuaian 80,61\%. (d) Waktu pertemuan saya dengan pegawai dengan tingkat kesesuaian 92,86\%. (e) Waktu yang diperlukan teller untuk bertransaksi dengan tingkat kesesuaian 83,09\%. (f)Waktu menunggu di antrian di ATM dengan tingkat kesesuaian82,81\%.

Program undian berhadiah yang diadakan oleh bank dengan tingkat kesesuaian 78,02\%.

$$
\text { Kuadran IV dan harus }
$$
dilaksanakan sesuai dengan harapan nasabah adalah (a)Perhatian teller kepada nasabah dengan tingkat kesesuaian 74,80\%. (b) Kesungguhan semua karyawan melayani nasabah dengan tingkat kesesuaian 70,19\%. (c)Waktu menunggu di antrian dengan tingkat kesesuaian 72,65\%. d. Keberadaan mesin ATM dengan tingkat kesesuaian 97.74\%. (e.)Tingkat suku bunga yang diberikan bank selama ini dengan tingkat kesesuaian $69,30 \%$.

\section{KESIMPULAN}

1. Faktor-faktor yangterdapat pada Kuadran I merupakan faktorfaktor yang perlu di pertahankan pelaksanaannya, karena sudah sesuai dengan harapan pelanggan(a). Pelayanan transaksi kepada nasabah dengan tingkat kesesuaian 83,38\%. (b) Kecepatan teller melakukan transaksi dengan tingkat kesesuaian $82,48 \% \quad$ (c) Tanggapan teller kepada nasabah dengan tingkat kesesuaian 80,38\%. (d) Proses transaksi kepada nasabah dengan tingkat kesesuaian $79,22 \% \quad$ (e)Kesigapan teller melayani nasabah dengan tingkat kesesuaian82,91\%. (f)Kesungguhan teller melayani nasabah dengan tingkat kesesuaian89,62\%. Teller mendengarkan permintaan nasabah dengan tingkat kesesuaian $86,02 \%$. (h) Teller tahu bagaimana menangani suatu transaksi spesial yang nasabah minta dengan tingkat kesesuaian 85,60\%. (i)Kemampuan teller melakukan 
transaksi dengan tingkat dengan tingkat kesesuaian 92,86\%. kesesuaian 92,20\%.

2. Faktor-faktor yang terdapat pada Kuadran II merupakan faktorfaktor yang pelaksanaannya dilakukan dengan sangat baik oleh pihak bank, namun dinilai kurang penting oleh nasabah, sehingga terkesan berlebihan. Faktor-faktor tersebut antara lain: (a)Teller tidak minta bantuan dari teller lain untuk transaksi yangnasabah minta dengan tingkat kesesuaian $97,74 \%$.

3. Faktor-faktor yang terdapat pada Kuadran III merupakan faktorfaktor yang dinilai kurang pentingoleh nasabah, akan tetapi telah dilakukan dengan cukup oleh pihak bank. Faktor-faktor itu adalah (a) Waktu yang diperlukan seluruh transaksi dengan tingkat kesesuaian 81,74\%. (b) Waktu menunggu begitu sampai diloket dengan tingkat kesesuaian 80,55\%. (c)Sambutan segenap karyawan kepada nasabah dengan tingkat kesesuaian 80,61\%. (d)Waktu pertemuan saya dengan pegawai 


\section{DAFTAR PUSTAKA}

SejosenoAjiHaryoR,2002, Analisis Sikap Konumen Terhadap keputusan

MenjadiNasabahPT.BankRakyatIn donesia(Persero) CabangSleman, Skripsi tidak dipublukasikan, Yogyakarta.

Santoso, S., 2000, SPSS Statistik Parametrik, Elex Media Komputindo, Jakarta. Supranto, J., 1997, Pengukuran Tingkat Kepuasan Pelanggan, Rineka Cipta,Jakarta.

Supranto,J.,1992,

TeknikSamplingUntukSurveidanEk sperimen,RinekaCipta, Jakarta.
Sulistiono,Puji,,2015,IndikatorKepuasan PelangganDalamUpayaPemenuhan Elemen-elemen ISO 9001:2000, Tesis, Yogyakarta.

Usmara.A, 2003.Strategi Baru Manajemen Pemasaran, Amara Books, Yogyakarta.

O.P Simorangir, 1979, Dasar-dasar Mekanisme Perbankan, Aksara PersadaPress, Jakarta.

Kotler Philip, 1997, Manajemen Pemasaran Jilid 2, PT Prenhallindo, Jakarta.

KolterPhilip danAmstrong Garya, 1997, Dasar- dasar Pemasaran, PTPrenhallindo, Jakarta. 